\title{
Using of Electrodeposition Technique to remove Ra-226 from Contaminated soil
}

\author{
Rana Abd El Wahab ${ }^{1}$, A.M.El Shershabe ${ }^{2}$, M.R.Ezz El Din ${ }^{1}$, A.A.Taha ${ }^{1}$ \\ ${ }^{1}$ Radiation Protection department, Nuclear\& Radiological Regulatory Authority(ENRRA), \\ Nasr City, Cairo, Egypt \\ ${ }^{2}$ Department of Physics, Faculity of Women for Arts, Science and Education, Ain-Shams \\ University, Cairo, Egypt
}

\section{1-Abstract}

The aim of this study was to remove Ra-226 from the contaminated soil samples which collected from one of oil company located at western desert of Egypt. Five soil samples (S-1, S-2, S-3,S-4,S-5) were collected from the bottom of evaporation pond from different positions of dry evaporation pond inside the oil company. The activity concentration of Ra-226 measured by using the Hyper Pure Germanium detector (HPGe) connected to MCA . Electrodeposition technique was used to produce in situ metallic coatings by the action of an electric current on a conductive material immersed in a solution containing a salt of the metal to be deposited. Chemical agents added to the solution to increase the efficiency of contaminant removal nitric acid $\mathrm{HNO}_{3}$ was added to improve the solubility of Ra-226. Three different electrods made from stainless steel, aluminum and cupper poles were used in this study. The data obtained showed that the highest removal percentage of the Ra-226 found to be $73 \%$ when the aluminum pole was used. Therefore, from the obtained data, it is clear that the electrodeposition technique using aluminum poles for removal of Ra-226 can be used for remediation or treatment contaminated soil produced from oil industry.

Key Words: Electrodeposition , Decontamination, NORM , HPGe, contaminated soil

\section{2-Introduction}

Naturally Occurring Radioactive Materials (NORM's) are those materials that contain radioactive isotopes of ${ }^{238} \mathrm{U}$ and ${ }^{232} \mathrm{Th}$ and their progenies as well as ${ }^{40} \mathrm{~K}$. NORM's exist in soil, water, plants, animals, human, coal, lignite, petroleum, phosphate ores, geothermal wastes, wastewater...etc., in small varying amounts. On the other hand, nearly all the naturally occurring radioactive materials are considered in balance state.

\section{*Corresponding author: malikarahim2014@gmail.com}


The gamma radiation emitted from NORM is called terrestrial back ground radiation .materials such as rock, soil, under ground water and air contain various NORMS in different concentrations in various locations of the world were discussed in several studies. (Taqi.A.H, Al-Ani.L.A, et al,2016).

Many oil companies in the world have used to discharge the water co-produced with the production of oil and gas into the environment in unlined artificial lagoons and pits for evaporation pond. This evaporation ponds become with time highly contaminated with NORM. (Ezz El-Din.M.R, 2008).

Wastes associated with the various industrial activities, with enhanced levels of the natural radioactivity as a result of industrial process, causes what is called, "Technological Enhanced-Naturally Occurring Radioactive Materials", to be named as acronym word "TENORM". (Attallah. M. F, et al , 2012).

The precipitated TENORM wastes around walls of the petroleum pipes reduce their efficiency and then disposed and replaced periodically by new ones (El-Afifi.E.M, Awwad.N.S, 2009). Both hazardous and non-hazardous solid wastes are generated during the refining process. Refinery wastes are typically in the form of sludge, spent process catalysts, filter clay, and incinerator ash. In addition, produced water contains enhanced naturally occurring radioactive materials (NORM) resulting from the ${ }^{232}$ Th and ${ }^{238} \mathrm{U}$ series( Swann.c, et al, 2004) this water is currently considered to be the largest volume of radioactive waste generated by the petroleum industry . (Saleh.I.H, et al, 2018).

Levels of activity in the oil-produced water can attain several hundred Becquerels per liter, depending on the source rocks of the oil reservoirs and the associated brine water Al(Masri. M.S, 2006). Discharging these types of wastewater into the environment causes environmental pollution as surface and ground waters as well as in soil, and thus exposure to the public and the workers. (Al Attar. L, Safia. B, 2013).

During routine operations, workers in oil and gas fields are exposed to external gamma radiation. This external gamma radiation exposure is due to radioactive species precipitated at walls of pipes and vessels as well as that arising from TENORM contaminated soil. The dose rate at oil and gas fields could be in order of tens of micro Sievert per hour.(Ahmed.YA.A, et al, 2019).

NORM residues in the oil \& gas Industry are typical examples of precipitated materials. These materials are generated by precipitation or sorption of radionuclides from fluids (or gases). Regarding their genesis, different types of radioactive scale formation have been identified in the oil and gas industry resulting in different types of NORM waste. Due to 
differences in how the NORM waste occurs on the oil and gas installations it is beneficial to divide the waste into two categories:

a- NORM loose materials: sediments, produced sand, slop, material from pigging (cleaning of tubulars and other equipment)

b- NORM contaminated production equipment : production tubulars, other production equipment

The oil and gas production NORM waste as it occurs is most often mixed with other components such as heavy oil components (tar, wax). In addition to corrosion products and sand/clay was produced. Apart from their radioactive properties, the non-radioactive components may require classification as hazardous waste.

The activity concentration of NORM wastes follows typically a log-normal distribution. This must be taken into account when conceiving the measurement program.

The major factors influencing the occurrence of NORM in oil/gas production are:

1. Type of production. Oil and gas installations differ largely with respect to types and amounts of NORM.

2. NORM pre-history. It is usually well-known from the production phase where NORM is likely to be present on a given installation and what quantities that should be expected.

3. The cleanliness state of the installation. The amount of NORM left to be handled during decommissioning will depend on the grade of NORM waste recovery performed in the installation's shut-down phase.

4. The presence of oil storage tanks. If (produced) oil storage tanks are present, they may contain considerable amounts of NORM in bottom sediments.

5. The presence of pre-processing installations. If NORM is found to be present in the processing modules on the "mother" installation, it is likely that also "satellite" installations and the connecting pipelines and risers are NORM infected. ( Michele Peroni, et.al , 2012 ).

\section{3-Material, instrumentation and method}

\subsection{Materials}

\subsubsection{Collected Soil Samples}

The soil samples used in this study were collected from an evaporation pond of one of oil company located at western desert which considered one of highest contaminated soil in all areas surveyed undergone remediation technique in accordance with radiation protection principles. 
five soil samples(S-1, S-2, S-3,S-4,S-5) were collected from different positions at the bottom of dry evaporation pond located inside oil\& gas product field, Each sample were collected from the surface and sealed in $250 \mathrm{ml}$ marinelli container for three weeks in order to maintain secular equilibrium. were measured by using a high purity germanium (HPGe) detector. The detector is coupled to a multi-channel analyzer (MCA) model ISOXSRCE, Canberra.

\subsection{Instrumintation}

\subsubsection{Gamma Spectrometric Analysis:}

Gamma spectrometry is a powerful technique for determining qualitative and quantitative low-level natural radioactivity in environmental and geological samples through their gamma-ray emission.

The gamma spectrometric analysis of these samples enables a large number of nuclides to be covered in a single analysis without radiochemical treatment. The large number of publications on radiation monitoring, all over the world, indicates the reliability of gamma spectrometry. ( M. Abo-Elmagd, et.al, 2009).

\subsection{Method}

\subsubsection{Removal of Ra-226 by Using Electrodeposition}

Electrodeposition is a well-known method to produce in situ metallic coatings by the action of an electric current on a conductive material immersed in a solution containing a salt of the metal to be deposited (A.A.Taha, 2008).

Chemical agents added to the solution to increase the efficiency of contaminant removal. Acids, such as nitric acid, $\left(\mathrm{HNO}_{3}\right)(2 \mathrm{Moler})$ and added to improve the solubility of certain contaminants with added also the salt $\mathrm{NaOH}(1 \mathrm{Moler})$.

Removal of Ra-226 from contaminated soil by electro-deposition technique using different electrodes materials ( stainless steel poles ,aluminum poles and cupper poles), the data obtained are shown in the following tables before and after experiments at fixed time and fixed rate.

\section{4-Result \& Discussion}

The results of the present work may clear-up the risk of NORM to the environment and how to initiate method to deal with the radioactive contaminated soil. 


\subsection{Detarmination of Activity Concentration in the Investigated Soil Samples}

The activity concentration of the most important radionuclides in U-238 series and Th232 series in the investigated soil samples before using the electrodeposition technique were measured and shown in tables (1), and it will be used for comparison or calculation of removal percentages after using electrodeposition technique.

Table (1): The activity concentration in $\mathrm{Bq} / \mathrm{kg}$ of the investigated soil samples $( \pm$ SD $)$

\begin{tabular}{|c|c|c|c|c|c|}
\hline \multirow{2}{*}{$\begin{array}{c}\text { Sample } \\
\text { No. }\end{array}$} & \multicolumn{3}{|c|}{ U-238 (Bq/kg } & \multicolumn{1}{c|}{ Th-232 (Bq/kg $)$} \\
\cline { 2 - 6 } & Ra-226 & Pb-214 & Bi-214 & Ac-228 & Tl-208 \\
\hline S-1 & $45747 \pm 198$ & $30749 \pm 31$ & $50472 \pm 124$ & $44729 \pm 91$ & $22471 \pm 30$ \\
\hline S-2 & $40234 \pm 301$ & $22175 \pm 55$ & $42981 \pm 142$ & $37744 \pm 101$ & $20241 \pm 72$ \\
\hline S-3 & $49730 \pm 318$ & $44266 \pm 53$ & $72099 \pm 213$ & $46955 \pm 145$ & $19852 \pm 120$ \\
\hline S-4 & $59253 \pm 219$ & $48951 \pm 29$ & $80022 \pm 115$ & $57453 \pm 78$ & $19952 \pm 70$ \\
\hline S-5 & $22018 \pm 198$ & $15749 \pm 31$ & $24472 \pm 124$ & $22729 \pm 91$ & $10471 \pm 30$ \\
\hline
\end{tabular}

\subsection{Removal of Ra-226 from the contaminated soil using electrodeposition technique}

The removal of Ra-226 from the investigated soil samples was carried out using electrodeposition technique .The data obtained are shown in tables (2-7) and figure (1-3). From table(2) it is clear that the rate of removal of Ra-226 from the investigated soil samples (S-1) to (S-5) is varied from 55 to $61 \%$. while table(3) shows the variation of time with percentage of Ra-226 removal and it is found that the highest removal percentage was reach at 30 and 40 minutes using stainless steel poles with (S-1). 
Table (2): Ra-226 Deposition using Stainless Steel (S.S) Poles

\begin{tabular}{|c|c|c|c|c|}
\hline $\begin{array}{c}\text { Sample } \\
\text { No. }\end{array}$ & $\begin{array}{c}\text { Electrode } \\
\text { Type }\end{array}$ & $\begin{array}{c}\text { Ra-226 Activity } \\
\text { before experiment } \\
(\mathbf{B q} / \mathbf{k g})\end{array}$ & $\begin{array}{c}\text { Ra-226 Activity } \\
\text { after experiment } \\
(\mathbf{B q} / \mathbf{k g})\end{array}$ & $\begin{array}{c}\text { Radium } \\
\text { Deposit } \\
(\%)\end{array}$ \\
\hline S-1 & S.S & $45747 \pm 198$ & $17841.3 \pm 123$ & 61 \\
\hline S-2 & S.S & $40234 \pm 301$ & $16898.3 \pm 118$ & 58 \\
\hline S-3 & S.S & $49730 \pm 318$ & $22378.5 \pm 125$ & 55 \\
\hline S-4 & S.S & $59253 \pm 219$ & $26071 \pm 134$ & 56 \\
\hline S-5 & S.S & $22018 \pm 198$ & $9247.6 \pm 98$ & 58 \\
\hline
\end{tabular}

Table (3): The relationship between time (min) and rate of deposition of radium-226 Using Stainless Steel Poles and (S-1) Sample

\begin{tabular}{|c|c|c|c|}
\hline $\begin{array}{c}\text { Time } \\
\text { (min.) }\end{array}$ & $\begin{array}{c}\text { Ra-226 Activity } \\
\text { before Experiment } \\
(\mathbf{B q} / \mathbf{k g})\end{array}$ & $\begin{array}{c}\text { Ra-226 Activity } \\
\text { after Experiment } \\
\text { (Bq/kg) }\end{array}$ & $\begin{array}{c}\text { Radium } \\
\text { Deposit } \\
\text { (\%) }\end{array}$ \\
\hline $\mathbf{1 0}$ & $45747 \pm 198$ & $44603 \pm 127$ & 22 \\
\hline $\mathbf{2 0}$ & $45747 \pm 198$ & $36305 \pm 134$ & 49 \\
\hline $\mathbf{3 0}$ & $45747 \pm 198$ & $29044 \pm 178$ & 61 \\
\hline $\mathbf{4 0}$ & $45747 \pm 198$ & $21783 \pm 145$ & 61 \\
\hline $\mathbf{5 0}$ & $45747 \pm 198$ & $27488 \pm 167$ & 60 \\
\hline
\end{tabular}

Therefore, by using stainless steel poles for deposition, it is found that the deposition efficiency ranged between 22 to $61 \%$ while sample 1 (S-1) give the highest deposition percentage $(61 \%)$ 


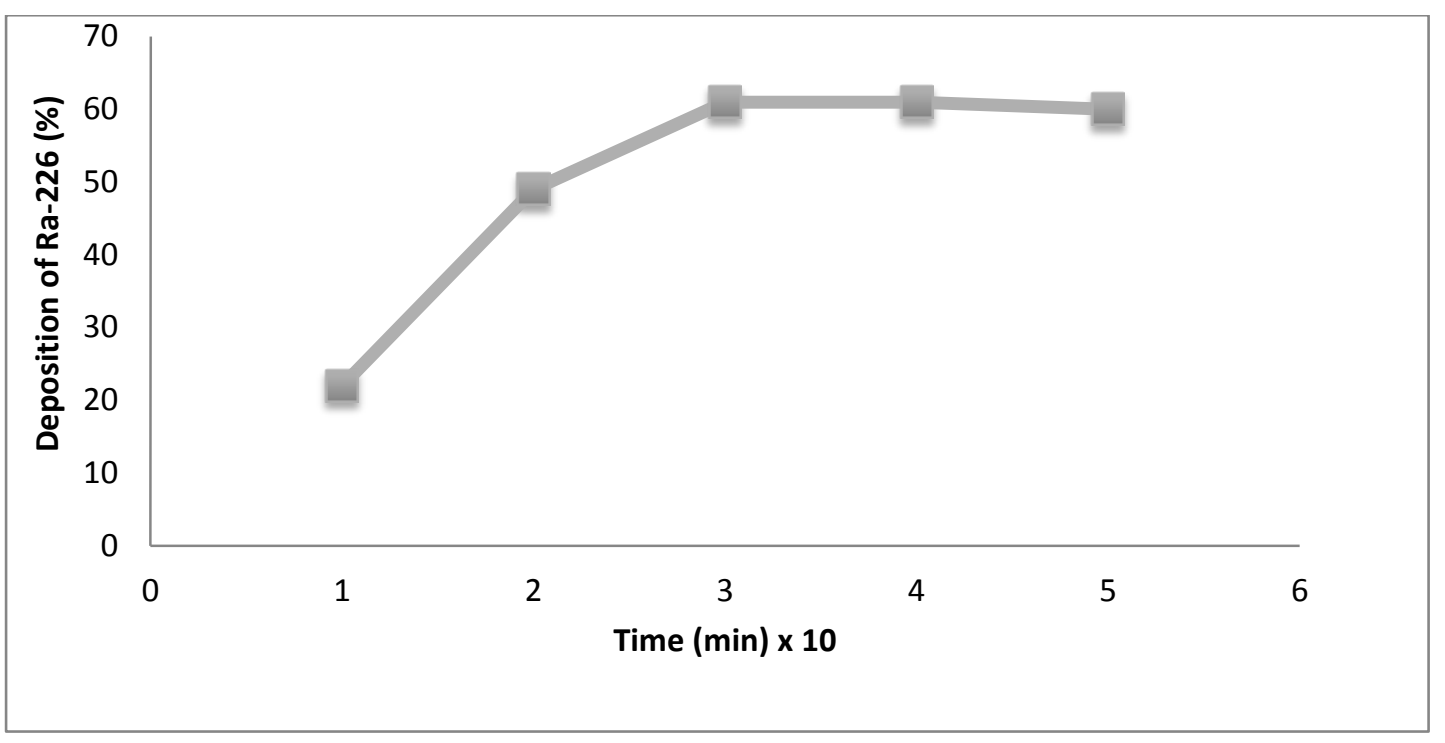

Figure (1): Electro-deposition of ${ }^{226} \mathbf{R a}$ as a function of electro-deposition time Using Stainless Steel Poles (S-1) Sample

Figure (1) shows the highest electro-deposition percentage achieved at 30 minutes then a little decrease between 40 and 50 minutes and with increasing time no more deposition due to saturation of the surface of stainless steel poles. So, it is found that the removal of Ra-226 take short time to electrodeposition on stainless steel poles. From table(4) it is clear that the $\%$ removal of Ra-226 from the investigated soil samples (S-1) to (S-5) is varied from 69 to $73 \%$, while table(5) shows the variation of time with \% of Ra-226 removal and it is found that the highest removal percentage was reach at 30 minutes using aluminum poles and (S-2).

Table (4): Ra-226 Deposition using aluminum poles

\begin{tabular}{|c|l|l|l|}
\hline $\begin{array}{l}\text { Sample } \\
\text { No. }\end{array}$ & $\begin{array}{l}\text { Ra-226 Activity } \\
\text { before experiment } \\
(\mathbf{B q} / \mathbf{k g})\end{array}$ & $\begin{array}{l}\text { Ra-226 Activity } \\
\text { after experiment } \\
(\mathbf{B q} / \mathbf{k g})\end{array}$ & $\begin{array}{l}\text { Radium } \\
\text { Deposit } \\
(\%)\end{array}$ \\
\hline S-1 & $45747 \pm 198$ & $12809 \pm 124$ & 72 \\
\hline S-2 & $40234 \pm 301$ & $10863 \pm 148$ & 73 \\
\hline S-3 & $49730 \pm 318$ & $15416 \pm 156$ & 69 \\
\hline S-4 & $59253 \pm 219$ & $16590 \pm 179$ & 72 \\
\hline S-5 & $22018 \pm 198$ & $6385 \pm 110$ & 71 \\
\hline
\end{tabular}


In case of using aluminum poles for electrodeposition, it is found that the deposition efficiency is varied between 69-73\% while sample 2 (S-2) give the highest deposition (73\%). Table (5) shows the relationship between time and rate of deposition of radium on aluminum electrode (Plateau Curve). Figures (2) show electro-deposition of Ra-226 as a function of electrodeposition time.

Table (5): The relationship between time and rate of deposition of radium-226 using aluminum poles and (S-2) sample

\begin{tabular}{|c|c|c|c|}
\hline $\begin{array}{c}\text { Time } \\
(\mathbf{m i n} .)\end{array}$ & $\begin{array}{c}\text { Ra-226 Activity } \\
\text { before Experiment } \\
(\mathbf{B q} / \mathbf{k g})\end{array}$ & $\begin{array}{c}\text { Ra-226 Activity } \\
\text { after Experiment } \\
(\mathbf{B q} / \mathbf{k g})\end{array}$ & $\begin{array}{c}\text { Radium } \\
\text { Deposit } \\
(\mathbf{\%})\end{array}$ \\
\hline $\mathbf{1 0}$ & $40234 \pm 301$ & $24542 \pm 158$ & 39 \\
\hline $\mathbf{2 0}$ & $40234 \pm 301$ & $18105 \pm 177$ & 55 \\
\hline $\mathbf{3 0}$ & $40234 \pm 301$ & $10863 \pm 185$ & 73 \\
\hline $\mathbf{4 0}$ & $40234 \pm 301$ & $11265 \pm 176$ & 72 \\
\hline $\mathbf{5 0}$ & $40234 \pm 301$ & $11265 \pm 176$ & 72 \\
\hline
\end{tabular}

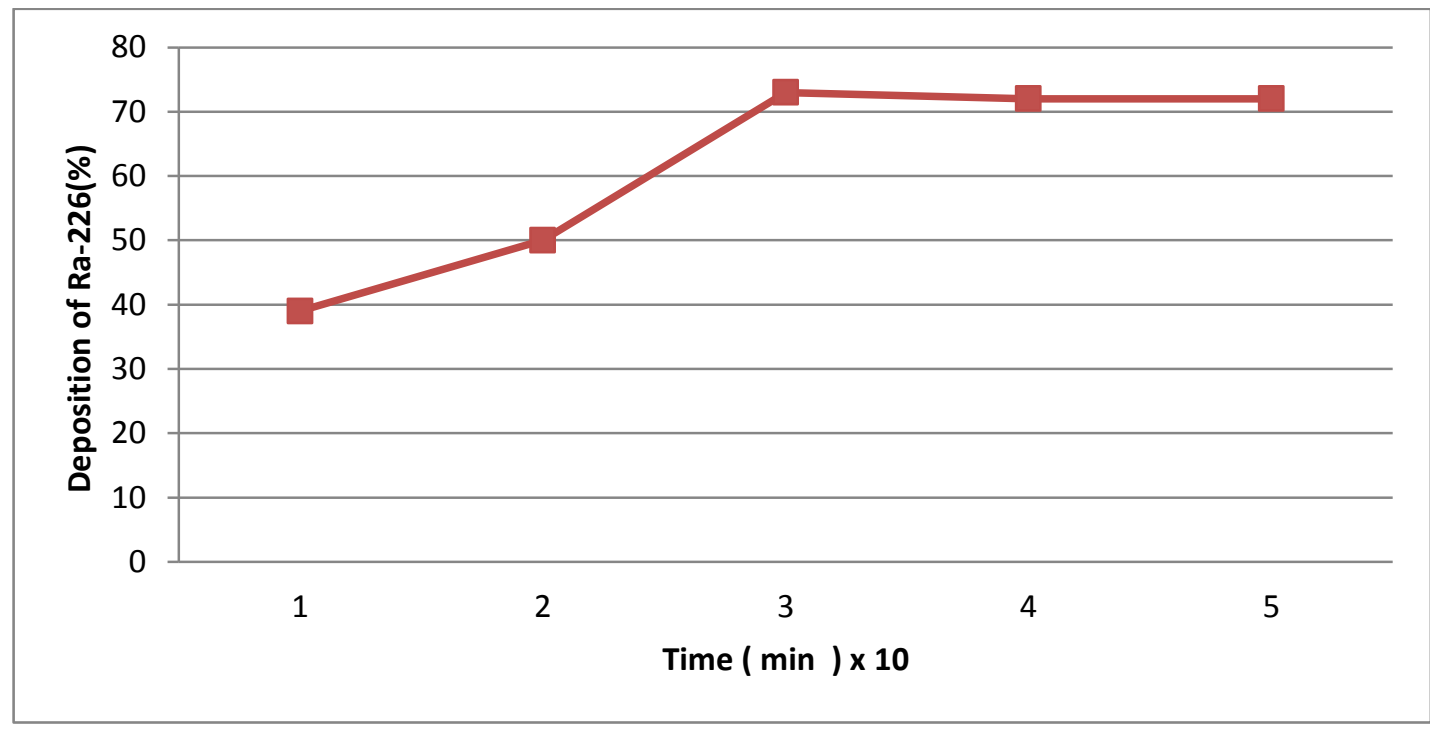

Figure (2): Electro-deposition of ${ }^{226} \mathrm{Ra}$ as a function of electro-deposition time using aluminum poles and (S-2) sample

In figure (2) it is show that the highest electro-deposition percentage was achieved at 30 minutes then a little decrease between 40 and 50 minutes and with increasing time no more deposition due to saturation of the surface of aluminum poles. So, it is found that the removal of Ra-226 take short time to electro deposition in aluminum poles. Table (5) show that the 
percentage of Radium deposition on aluminum electrodes is ranged between $39 \%$ to $73 \%$ through time $30 \mathrm{~min}$.

In case of using cupper poles, the data obtained are shown in table $(6,7)$ and figure (3). Table (6) shows the percentage of separation of radium using cupper poles and Table (7) shows the relationship between time and rate of deposition of radium on cupper electrode (Plateau Curve).

Table (6): Ra-226 Deposition using cupper poles

\begin{tabular}{|c|c|c|c|}
\hline $\begin{array}{c}\text { Sample } \\
\text { No. }\end{array}$ & $\begin{array}{c}\text { Ra-226 Activity } \\
\text { before experiment } \\
(\mathbf{B q} / \mathbf{k g})\end{array}$ & $\begin{array}{c}\text { Ra-226 Activity } \\
\text { after experiment } \\
(\mathbf{B q} / \mathbf{k g})\end{array}$ & $\begin{array}{c}\text { Radium } \\
\text { Deposit } \\
(\boldsymbol{\%})\end{array}$ \\
\hline S-1 & $45747 \pm 198$ & $36579 \pm 178$ & 20 \\
\hline S-2 & $40234 \pm 301$ & $30980 \pm 158$ & 23 \\
\hline S-3 & $49730 \pm 318$ & $39286 \pm 167$ & 21 \\
\hline S-4 & $59253 \pm 219$ & $45032 \pm 128$ & 24 \\
\hline S-5 & $22018 \pm 198$ & $17834 \pm 120$ & 19 \\
\hline
\end{tabular}

Table (7): The relationship between time and rate of deposition of radium-226 on cupper poles and (S-4) sample

\begin{tabular}{|c|c|c|c|}
\hline $\begin{array}{c}\text { Time } \\
\text { (min.) }\end{array}$ & $\begin{array}{c}\text { Ra-226 Activity } \\
\text { before Experiment } \\
\text { (Bq/kg) }\end{array}$ & $\begin{array}{c}\text { Ra-226 Activity } \\
\text { after Experiment } \\
\text { (Bq/kg) }\end{array}$ & $\begin{array}{c}\text { Radium } \\
\text { Deposit } \\
(\mathbf{\%})\end{array}$ \\
\hline $\mathbf{1 0}$ & $59253 \pm 219$ & $54512 \pm 89$ & 8 \\
\hline $\mathbf{2 0}$ & $59253 \pm 219$ & $52735 \pm 78$ & 11 \\
\hline $\mathbf{3 0}$ & $59253 \pm 219$ & $49772 \pm 120$ & 16 \\
\hline $\mathbf{4 0}$ & $59253 \pm 219$ & $45032 \pm 143$ & 24 \\
\hline $\mathbf{5 0}$ & $59253 \pm 219$ & $45624 \pm 134$ & 23 \\
\hline $\mathbf{6 0}$ & $59253 \pm 219$ & $47402 \pm 144$ & 20 \\
\hline
\end{tabular}


From the data obtained in table (7) the deposition efficiency using cupper poles was varied between 19-24\% while sample 4 (S-4) give the highest deposition (24\%)

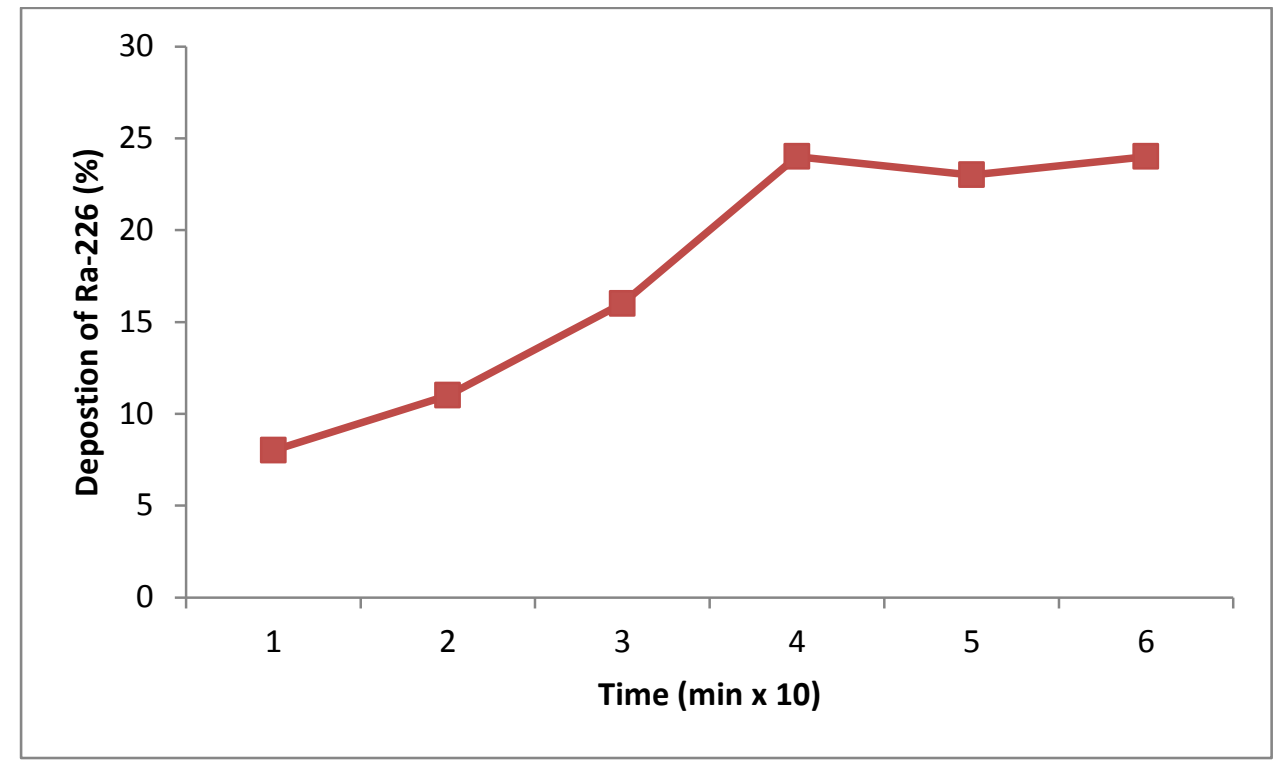

\section{Figure (3): Electro-deposition of ${ }^{226}$ Ra as a function of electro-deposition time using cupper poles and (S-4) sample}

Figure(3) shows that the highest electrodeposition percentage was achieved at 40 minutes then a little decrease between 50 and 60 minutes and with increasing time no more deposition due to saturation of the surface of cupper poles. So, it is found that the removal of Ra-226 take short time for electrodeposition on cupper poles.

\section{Conclusion}

In conclusion, The collected soil samples have been found to be highly contaminated with NORM, (Ra-226). With respect to this fact the electro-deposition technique used in this study as a removal technique to decrease the concentration of Ra-226 in the investigated soil by using different electrode materials ( stainless steel, aluminum and Cupper electrodes).

Remarkable progress has been achieved by this technique as shown in the followings:

- $61 \%$ removal efficiency of (Ra-226) by using the stainless steel electrodes

- $73 \%$ removal efficiency of (Ra-226) by using the Aluminum electrodes

- $24 \%$ removal efficiency of (Ra-226) by using the copper electrodes.

Therefore, it is clear that the aluminum poles was the best electrodes to deposit the Radium-226. Therefore, from the obtained data, it is clear that the electrodeposition technique using aluminum poles for removal of Ra-226 can be used for remediation or treatment of contaminated soil produced from oil industry. 


\section{Reference}

Al Attar. L, Safia. B, Journal of Environmental Management 124, 156-164, Sorption of 226Ra from oil effluents onto synthetic cation exchangers, 2013.

Abo-Elmagd. M, Soliman. H.A, et.al, Radiological hazards of TENORM in the wasted petroleum pipes, Journal of Environmental Radioactivity, 2009.

Ahmed. YA.A, Mahmoud. R.M.M, Ezz El-Din. M.R and Khalil. M. M. H, Arab J. Nucl. Sci. Appl., Vol. XX, X, 1-9, Radiological Hazards of TENORM Contaminated Soil at Oil and Gas Fields, 2019.

Al-Masri. M.S, Isot, 64, 615-623, Appl. Radiat, Spatial and monthly variations of radium isotopes in produced water during oil production, 2006.

Attallah. M.F, Awwad. N.S and Aly. H.F, chapter 4, Environmental Radioactivity of TENORM Waste Produced from Petroleum Industry in Egypt: Review on Characterization and Treatment, 2012.

El Afifi. E.M, Awwad. N.S, Hilal. M.A, J. Haz. Mat, 161, 907-912, Sequential chemical treatment of radium species in TENORM waste sludge produced from oil and natural gas production, 2009.

Ezz El-Din. M.R, Isotope\& RAD. RES,40(3), 719-732, Remediation of radioactively contaminated soil by physical and chemical separation processes, 2008.

Peroni. M, Mulas. V, Patata, et.al , Saipem S.p.A. - Via Toniolo 1, 61032, Fano (PU) - Italy, Decommissioning and Remediation of NORM/TENORM Contaminated Sites in Oil and Gas, 2012.

Saleh. I. H, Othman. I. M, Ghatass. Z.F and Metwally. M.A, Arab J. Nucl. Sci. Appl., Vol. 51, 4, 31-43, Radiological Risk Assessment in a Type of Complex Petroleum Refinery in Egypt, 2018.

Swann. C, Matthews. J, Ericksen. R, Kuszmaul. J, US Department of Energy, DE-FG2602NT 15227, Evaluation of Radionuclides of Uranium, Thorium and Radium Associated with Produced Fluids, Precipitates and Sludges from Oil, Gas and Oilfields Brine Injections Wells in Mississippi, 2004.

Tahaa. A.A, ph-D, Some Radiological Stdies On Contaminated Water Associated With Oil Production And The Tretment Methods Needed To Protect Personal And Enviroment, 2008. 
Taqi. A.H, Al-Ani. L.A, Ali. A.M., Elsevier, Assessment of natural radioactive levels in Kirkuk oil field, 2016.

\section{الملخص باللغة العربية}

\section{استخدام تقتية الترسيب الكهربائى لازالة الر اديوم- Y r من التربة الملوثة}

رانا عبد الوهاب عبد المطلب'، امال محمود فرج الثرشابى '، محمد رضا عز الدين'، احمد عادل طه '

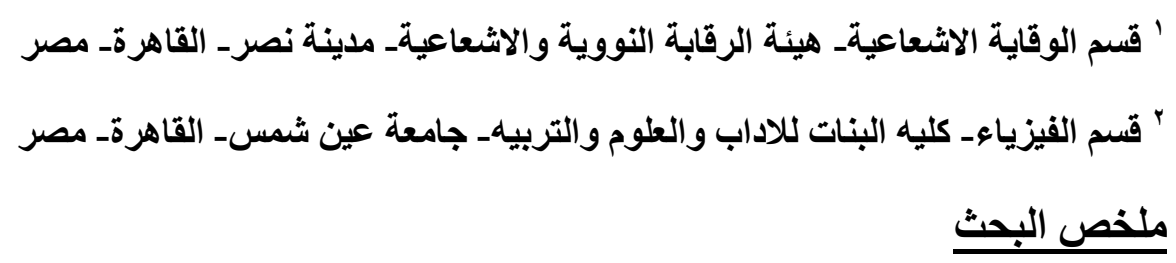

تهدف هذه الدر اسة إلى إز الة الر اديوم _TrY من عينات التربة الملوثة اشعاعيا والتي تم جمعها من إحدى

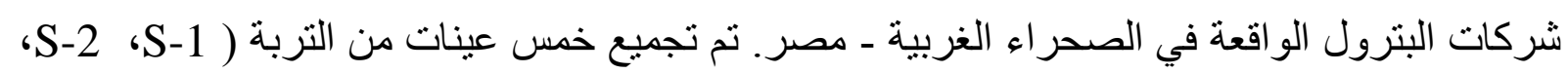
(S-5 ، من نقاط مختلفة بقاع بركة متبخرة داخل شركة البترول. تم قياس تركيز نشاط

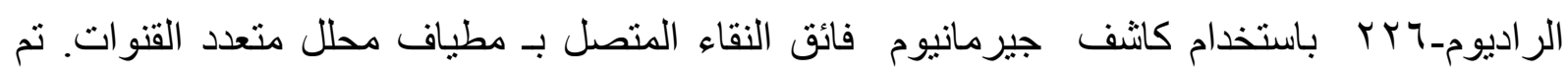
استخدام تقنية الترسيب الكهربائى من خلال عمل تيار كهربائي على مادة موصلة مغمورة في عينات التربة محل الدراسة واضافة حض النيتريك HNO3 لتحسين قابلية ذوبان الراديوم-؟Y ب بمحلول التربة. تم استخدام ثلاثة أقطاب كهربائية مختلفة مصنو عة من الاستانليس ستيل و الألومنيوم و النحاس في

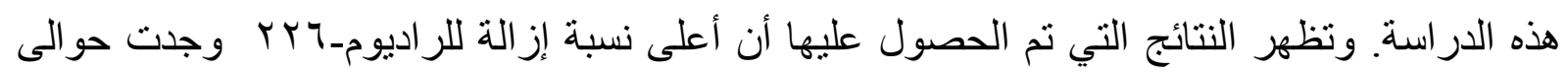
r \% ع عند استخدام أعمدة الألومنيوم، بينما الاقطاب الاخرى اعطت نسب اقل من ذلك وهى آه\% للاستانليس ستيل و ع \% \% للنحاس . ل لللك من خلال هذه النتائج يتضح أن تقنية الترسيب الكهربائى باستخدام أعمدة الألومنيوم لإز الة الر اديوم يمكن استخدامها كطريقة بديلة لمعالجة التربة الملوثة اشعاعياو الناتجة ببعض مو اقع حقول شركات البترول. 